\title{
Reverse Diffusion in US Multinationals: Barriers from the American Business System
}

\section{Tony Edwards, Phil Almond, Ian Clark, Trevor Colling and Anthony Ferner}

Management Department, King's College, London; Centre for Labour Market Studies, Leicester University; Kent Business School, University of Kent; Industrial Relations Research Unit, Warwick University; Leicester Business School, De Montfort University

ABSTRACT This paper addresses the issue of 'reverse diffusion' of employment practices in multinational companies, which is defined as the transfer of practices from foreign subsidiaries to operations in the country of origin. It adds to the literature by examining the influence of the parent business system in multinationals. Specifically, it addresses how the dominant institutions and established organizational structures and practices in the home country affect the extent and impact of reverse diffusion of employment practices. Drawing on fresh evidence from American-owned multinationals in the UK we argue that there is considerable potential for reverse diffusion to occur among this group of firms. However, we highlight a number of barriers to reverse diffusion that the American business system presents, demonstrating that these constrain both the prevalence and the impact of it in practice.

\section{INTRODUCTION}

There is growing interest in the way multinational companies (MNCs) transfer across borders practices originating in their foreign subsidiaries. Many models of strategy in MNCs (e.g. Bartlett and Ghoshal, 1998) and of international HRM (e.g. Bird et al., 1998) make conceptual allowance for this. Yet, there is little evidence on this phenomenon, most of which focuses on knowledge transfer across the firm (e.g. Foss and Pedersen, 2002). There is also a small but growing literature on 'reverse diffusion' (RD) of employment practices (e.g. Edwards and Ferner, 2004), defined as the transfer of practices from foreign subsidiaries to operations Street, London SE1 9NN, UK (tony.edwards@kcl.ac.uk). 
in the country of origin. This paper adds to the literature on RD by examining the influence of the parent business system. Specifically, it addresses how the dominant institutions and established organizational structures and practices in the home country affect the extent and impact of RD of employment practices. The available evidence on this issue is patchy, with the absence of studies of the phenomenon in US MNGs particularly notable. The paper draws on fresh evidence from American-owned firms in the UK to address this issue.

There are several reasons why the US business system might be receptive to RD. First, comparatively, the American labour market is relatively deregulated and there are few institutional constraints in the labour market to MNCs implementing practices diffused from foreign subsidiaries. Second, American firms tend to make frequent and substantial changes to their strategies, structures and practices. Firms in 'liberal market economies' (LMEs), such as the USA, are more likely than their counterparts in 'co-ordinated market economies' (CMEs) to engage in 'radical' innovations, defined as 'substantial shifts in product lines, the development of entirely new goods, or major changes in the production process' (Hall and Soskice, 2001, pp. 38-9). This disposition provides fertile ground for the introduction of new practices from abroad that represent a departure from established practices in the domestic operations. Third, as Whitley (2001) has argued, firms from 'arms-length environments' (a concept that is similar to an LME) are more willing and able than firms from 'collaborative business environments' (similar to CMEs) to undertake major switches of resources to novel uses including significant investments abroad; this creates conditions conducive to RD since foreign operations form a significant part of the wider firm. Moreover, Whitley argues that MNGs from arms-length environments tend to allow their foreign units considerable autonomy within tight financial constraints, enabling the foreign subsidiaries of such firms to quickly develop 'distinctive organizational capabilities' (2001, p. 50). Accordingly, Lam (2003) argues that the liberal institutional environment in the home country has encouraged American MNGs to develop significant capacity for 'globally dispersed learning'.

There are also reasons for expecting Britain to be the origin for RD in US MNCs. First, the British labour market is not as deregulated as its American counterpart, but the lack of constraining institutions affords British managers scope to innovate and develop 'distinctive capabilities'. Second, Britain receives 14 per cent of the total stock of foreign direct investments (FDI) made by American companies (UN, 2002). Consequently, at company level the British operations commonly form a large part of the wider firm and hence are an important 'centre of gravity'. Third, and relatedly, the openness of the British economy to FDI makes it a potential site for learning for MNCs. For example, MNCs may look to the UK to see how Japanese MNGs implemented such practices as continuous improvement techniques outside the home country. Fourth, the compatibilities between many aspects of the British and American business systems - such as a common lan- 
guage and their status as LMEs - creates a similar context across which quite novel practices can be transferred.

Numerous aspects of both the American and British business systems, therefore, lead us to hypothesize that RD is an important phenomenon in US MNGs in Britain. Our analysis makes use of a distinction between 'evolutionary' and 'transformative' RD. The former refers to diffusion that is directed towards an optimal mix of practices within an existing modus operandi, leading to only modest changes to employment relations in the firm's domestic plants; the latter type of RD shifts the firm to a new modus operandi, thereby bringing about more radical change (Edwards and Ferner, 2004). Based on five case studies, we investigate the role of the American business system in influencing the extent and impact of RD. We present evidence of UK sites playing significant roles in the development of new employment policies, producing some instances of RD. However, despite the grounds identified above for expecting the British operations to be important sources of novel practices that are transferred across sites within American MNCs, our evidence produced relatively few instances of evolutionary RD and none of transformative RD. Using an institutionalist approach, we explain these findings by analysing the barriers to RD that the American business system presents. The paper is structured as follows: the limited literature concerned with RD of employment practices is reviewed in the next section; the nature of the data used in the paper are described in the third part; the main empirical findings are presented in the fourth part; and the institutional barriers arising from the American business system are discussed in the penultimate section. Finally, the wider implications and conclusions of the paper are discussed.

\section{LITERATURE REVIEW}

Following the arguments above, we might expect $\mathrm{RD}$ to be more prevalent, and more radical in its effects, in MNCs from LMEs when compared with those from CMEs. Is the available evidence consistent with this prediction?

One source relates to British MNCs. Case studies have demonstrated that some British firms use their foreign subsidiaries as sites for learning about new practices where the domestic economy does not provide an attractive template on which to base international policies. For instance, Edwards' (1998) analysis of Engineering Products showed how management spread practices developed in its Spanish and French plants, such as cellular working and semi-autonomous teams, across its sites. These innovations caused 'transformative' changes to the nature of work organization in the domestic plants. However, the wider study from which this case was drawn indicates that RD is not widespread in British MNGs; indeed, in eight of the ten firms there was no evidence of $\mathrm{RD}$, and in the remaining one $\mathrm{RD}$ was evolutionary rather than transformative (Edwards, 2000). In short, while RD can be transformative in British MNCs, it does not appear to be particularly prevalent. 
There are a number of strands of evidence relating to MNGs from CMEs. Some of these produce instances of RD that are evolutionary in nature. For instance, in a significant though not radical innovation, some Japanese MNCs have altered their style of management domestically to incorporate the practice of 'positive reinforcement' - praising employees who have performed a task well - after observing this in their American subsidiaries (Cutcher-Gershenfeld et al., 1998, p. 44). A further instance is found in Sewell and Wilkinson's (1993) case study of an electronics firm that regularly updated its 'assembly manual' concerning the nature of work organization in the light of improvements made in the foreign subsidiaries. This is evolutionary RD because the basic parameters of the company's approach to work organization are established and amendments are within this framework.

Further evidence of RD in Japanese MNGs stems from Whitley et al.'s (2003) examination of financial services multinationals. This revealed evidence of firms developing new competencies and approaches based on the practices in their London and New York offices, such as the move away from 'the old Japanese model of a generalist banker' towards managers having specialist skills in international banking. However, the moves towards learning from foreign operations were limited, restricted partly by the separation of career structures for domestic and foreign managers. The authors' comparable study of Japanese car producers found hardly any evidence of learning from abroad. They argued that this was due to the internationalization strategies of these firms being based on a 'home based model' of production. Their extensive use of expatriate managers were not being encouraged to 'develop novel kinds of capabilities in diverse environments that could lead to the adaptation of the basic recipe' (2003, p. 668).

A further instance of evolutionary RD in MNGs from CMEs stems from Belanger et al.'s (1999) study of ABB, where the Finnish plant developed 'a specific competitive advantage by developing a seamless engineering and manufacturing flow' (p. 211) that eliminated 'indirect' staff and integrated administrative and engineering tasks into teams of workers. The Ludvika plant in one of the parent countries, Sweden, subsequently implemented some of the practices that had been developed in Finland. While this initiative brought about significant change to established practices at Ludvika and elsewhere, the innovation was in line with the 'Common Product' concept that the division favoured, and hence the impact was evolutionary.

While these cases of evolutionary RD in MNCs from CMEs are in line with our initial expectations, there are other sources of evidence that are not. Many German MNCs have shed the influence of the parent business system as they have internationalized, adopting strategies, structures and practices that represent a marked departure from those traditionally found in Germany (Ferner and Quintanilla, 1998; Ferner and Varul, 2000; Lane, 2001; Sally, 1996). For example, Lane (2001) chronicles some significant changes among seven 'flagship' German MNCs, though the extent of change was uneven: many have increased their investments 
in 'geographically and culturally more remote countries'; most have moved towards a 'network structure' with greater devolution to subsidiaries; and some have established listings on a number of stock markets, albeit with most of the voting rights remaining with German shareholders. In a similar vein, Ferner and Varul (2000) found that many German MNCs have removed the hierarchical decision-making structures characteristic of German firms, introducing instead the devolved business units used by large British and American MNGs. Accompanying these shifts have been associated effects in 'downstream' functions like HRM, with the introduction of 'Anglo-Saxon' style forms of remuneration for managerial staff, such as performance-related pay, share options and the like. Ferner and Varul present evidence testifying to the British subsidiaries playing leading roles in the development of new HR policies in relation to performance management, management development and explicit 'corporate cultures'. While these changes were implemented in the 'German manner', they nevertheless had a significant impact on the way the firms operated. Tempel's (2001) study of German MNCs produced a similar picture; in two of three cases the parent firm adopted practices operating initially in the British subsidiaries, such as the transfer of a performance management system in a German pharmaceuticals firm that represented a marked departure from pre-existing practice. Evidently, the operation of reverse diffused practices is conditioned by the German context; the implementation of 'variable' pay is a prime example (Kurdelbusch, 2002). Despite the constraining impact of German labour market institutions, however, the overall picture in German MNGs is of RD being prevalent, often causing transformative effects.

Evidence from other CMEs also throws up instances of transformative RD. Mtar's (2001) case studies of French MNCs indicated that many are undergoing similar changes to those apparent in German MNCs. In some French companies the UK sites were used as pioneers of new practices, enabling the company to observe new forms of control and use these to move away from the rigid, centralized and bureaucratic modes of control that had characterized the French plants. In the case of St Gobain, Mtar (2001, pp. 206-10) argues that the French part of the business used the British site's 'lean and reactive structures' as a model for reorganization, representing a significant departure from the hierarchical structure.

A study of a highly internationalized Swedish multinational (Hayden and Edwards, 2001) also found evidence of the firm using its British operations to depart from forms of remuneration which had been a key feature of the Swedish business system, particularly the narrow dispersion of pay within and between different occupational groups and the 'fixed' nature of pay. Management introduced a range of 'variable' forms of pay that linked remuneration to the performance of the individual, the business unit and the firm as a whole, significantly widening pay differentials. The authors argue that this process eroded, though did not eradicate, the 'fundamental characteristics' of the firm. 
The available evidence is clearly limited. However, it does lead us to question our initial expectations in a number of ways. First, it appears that the impact of labour market regulations in constraining RD in MNCs from CMEs is not as great as had been anticipated. In Germany, France and Sweden the institutional configurations have not closed off all scope for RD that has transformative effects. Second, the impact of CMEs in constraining the extent to which firms undertake radical changes through RD should not be exaggerated. In particular, MNGs that are at an advanced stage of internationalization can use RD to make substantial shifts in their modus operandi. Third, while broad categories such as CMEs and LMEs are a useful starting point, we need to focus on the nationally specific aspects of business systems. In particular, we should examine the way in which each national system is more or less conducive to RD in particular areas of HRM and industrial relations (IR). Specifically, the evidence suggests that RD occurs where the domestic business system is weak, or at least perceived to be so by senior managers.

Given the ambiguities in the available evidence, the questions relating to American multinationals become even more pertinent. Are the constraints of the US labour market as weak as we originally expected? Does the tendency of US firms to reinvent themselves through radical changes really promote RD? And do the structures of American MNGs genuinely allow foreign subsidiaries scope to lead the introduction of new practices across the firms? In the next section we outline the way in which the data that were gathered.

\section{METHOD}

The evidence stems from five case studies of American MNGs. All five cases exhibit some of the features of the 'transnational' firm as set out by Bartlett and Ghoshal (1998). These firms exhibit a well-developed international network, with strong management structures linking operating units that have interdependencies in production across borders. Moreover, 'transnationals' are not concentrated in any one country, and have gradually evolved towards this structure. A key part of the 'transnational' is that they are equipped to transfer knowledge and expertise across their sites wherever it originates. Bartlett and Ghoshal's typology, together with other theoretical work on MNGs, has been used to distinguish particular corporate characteristics that promote RD. The case study firms display most or all of these. Table I shows that: all the companies have incorporated a significant international dimension into a matrix structure, albeit to varying degrees; all operate in closely related businesses; production or service provision processes are highly standardized internationally in four of the companies; and all five have almost half of their employees outside the USA, have operated internationally for several decades and have grown at least partly through acquisition. In short, these are precisely the type of MNGs in which we might expect to find RD (see Edwards and Ferner (2004) for a fuller discussion of how these characteristics promote RD). 
Reverse Diffusion in US Multinationals

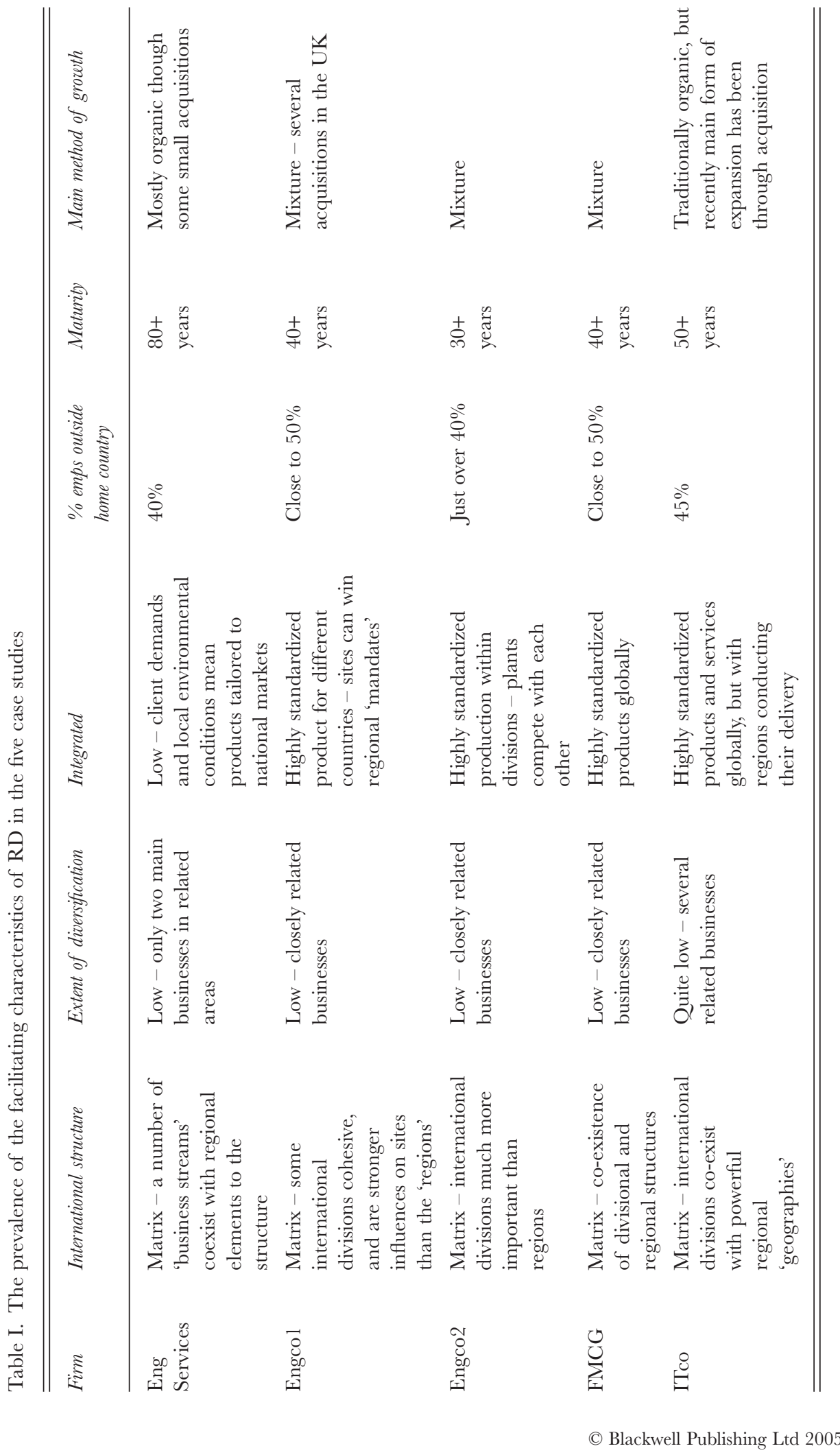


Table II. Fieldwork details in the case study firms

\begin{tabular}{|c|c|c|c|c|c|}
\hline \multirow[t]{2}{*}{ Firm } & \multirow[t]{2}{*}{ Sector and division } & \multicolumn{4}{|l|}{ Interviews } \\
\hline & & $\begin{array}{l}\text { UK } \\
\text { subsidiary }\end{array}$ & $\begin{array}{l}\text { American } \\
H Q\end{array}$ & $\begin{array}{l}\text { European } \\
H Q\end{array}$ & Total \\
\hline Eng Servs & $\begin{array}{l}\text { Sector: civil engineering contracting } \\
\text { Division: engineering and construction }\end{array}$ & 22 & 3 & - & 25 \\
\hline Engcol & $\begin{array}{l}\text { Sector: mechanical engineering } \\
\text { Division: specialist vehicles }\end{array}$ & 20 & 4 & - & 24 \\
\hline Engco2 & $\begin{array}{l}\text { Sector: mechanical engineering } \\
\text { Division: engines }\end{array}$ & 18 & 11 & - & 29 \\
\hline FMCG & $\begin{array}{l}\text { Sector: consumer goods } \\
\text { Division: chemical product }\end{array}$ & 16 & 4 & 2 & 22 \\
\hline ITco & $\begin{array}{l}\text { Sector: IT } \\
\text { Division: IT services }\end{array}$ & 21 & 4 & 4 & 29 \\
\hline Total & & 97 & 26 & 6 & 129 \\
\hline
\end{tabular}

Therefore, if we do not find instances of $\mathrm{RD}$ in these firms it is unlikely that this is due to their organizational characteristics and more likely to be due to features of the American business system.

The data were drawn primarily from in-depth interviews in the UK and USA. The British operations were studied in detail. Interviews were conducted with a range of managerial staff, both in HR and other functions, and around ten nonmanagerial employees were also interviewed, providing a good picture of employment practice in the sites and of the role of these sites within the wider firms. However, to ascertain the extent and impact of RD it was necessary to gather information from the USA. This was achieved in all five case studies. Where possible and appropriate, interviews were also conducted at the European HQ. In total, 129 interviews were conducted (see Table II).

These interviews focused on both the nature of formal policies and their operation in practice. They were sufficiently wide ranging to allow respondents to identify instances of RD in areas where we did not anticipate it. However, in each case data were gathered in relation to pay and performance management, work organization, and training and development. These three areas are ones in which RD has been found in previous work and this provided comparability across firms. In addition, the issue of employee representation was covered given the potentially important role that this has in amending transferred practices. The nature of the HR function was also covered in order to throw light on the process of diffusion.

An important methodological question concerns the evidence required to establish whether RD has occurred. Principally, we searched for practices in the domestic operations that had originated in the firm's British sites. Through extensive 
questioning we detected several instances of $\mathrm{RD}$ and we gathered multiple perspectives on each. In addition, we looked at the formation of international HR policies, partly to shed light on the process of diffusion but also to ascertain the extent to which the cases are characterized by modes of corporate control that reflect their American origins. Accordingly, interviews focused on such formal mechanisms as international committees, task forces and working groups, as well as more informal ones such as the transfer of staff across sites.

We subsequently distinguished between evolutionary and transformative RD. The responses to questions concerned with the impact of $\mathrm{RD}$ on employment policy and practice were used to make this assessment. Specifically, we assessed whether RD had challenged the fundamental characteristics of the organization in general and the nature of employment practice in the domestic operations in particular. In the event, a neat distinction between those instances of RD that were evolutionary and those that were transformative was not always possible, and the categorization became more a matter of degree than an absolute judgement.

The data do, of course, have limitations. The level of access, and hence the amount of data collected, varied to some extent across the firms. Moreover, the case study method inevitably means that the scope for generalizations across MNCs is limited, and so this evidence is not used to make strong claims about an entire nationality of MNCs. Further, we cannot be sure that we have not missed instances of RD in the cases. Our research design and specific line of questioning was sensitive to the variety of ways in which RD can occur and the use of interviewing at multiple levels was crucial in overcoming this potential problem. Nonetheless, it is conceivable that some cases of RD went undetected.

However, the data have many significant strengths. Uppermost amongst these is that the data are drawn from multiple levels and varied perspectives. In all cases respondents ranged from very senior levels - sometimes the corporate HR Director - to relatively junior positions such as semi-skilled operators. This avoids the problem of relying only on data from foreign subsidiaries, which risks downplaying the role of the corporate HQ and, more importantly, is not ideal for assessing the operation and impact of practices in the domestic operations. A further crucial strength concerns the extent of the fieldwork; we know of no other study of RD that draws on more than one hundred interviews across two countries. Overall, then, we feel that the quality of the data positions us to shed considerable light on reverse diffusion in US MNGs.

\section{THE EXTENT AND IMPACT OF REVERSE DIFFUSION}

In this section we present data on the extent and impact of reverse diffusion in our five cases. The key information from each company is presented in Table III, which demonstrates that five instances of RD were detected, all of which were evolutionary. 


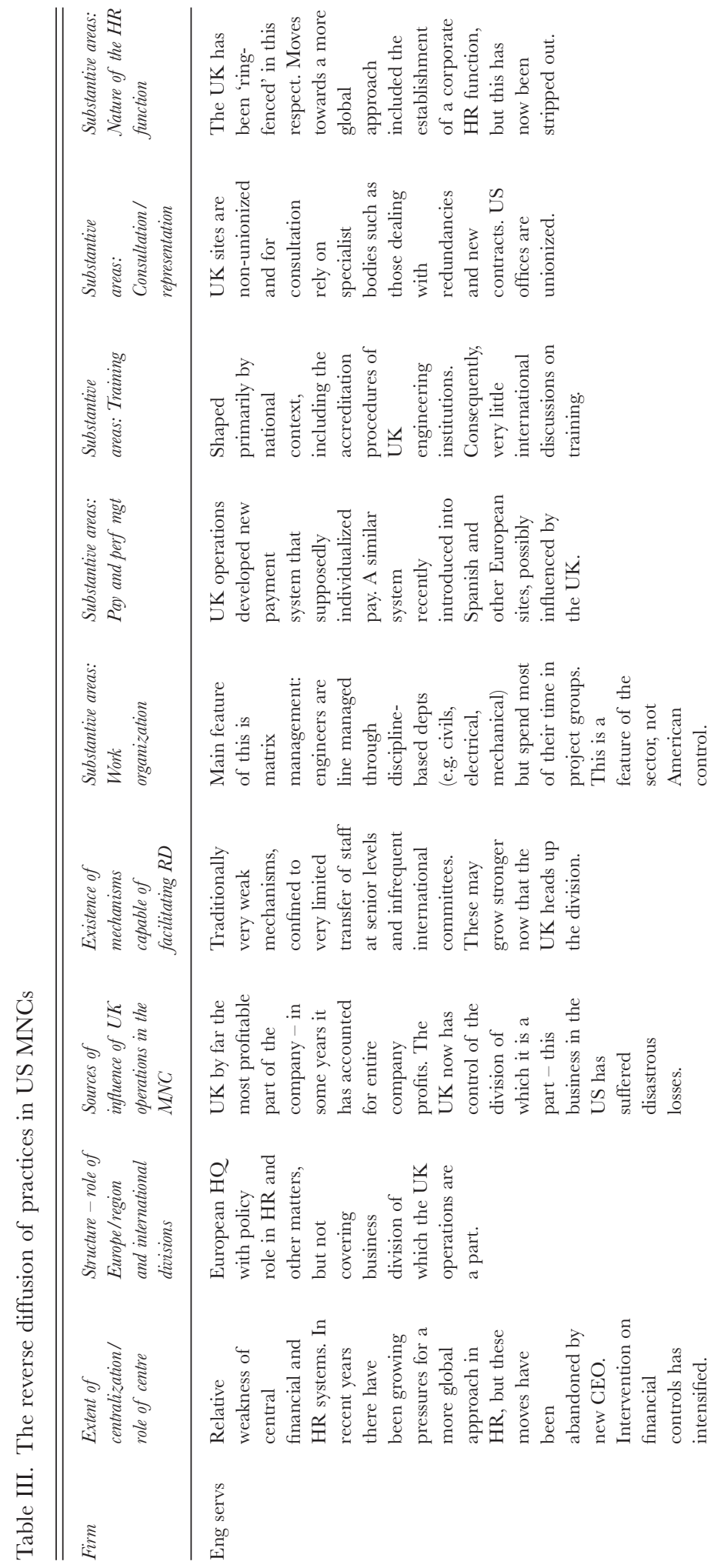




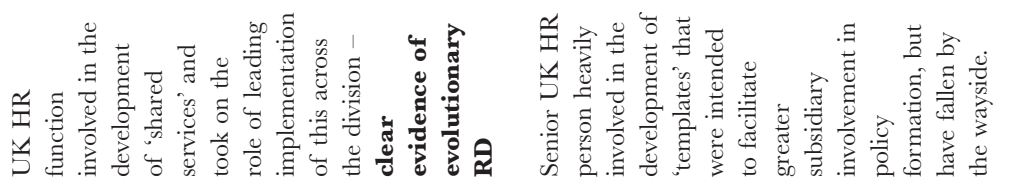

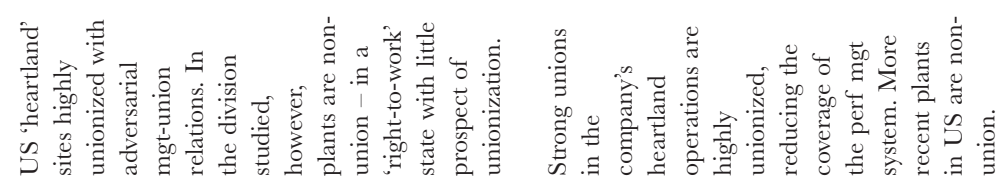

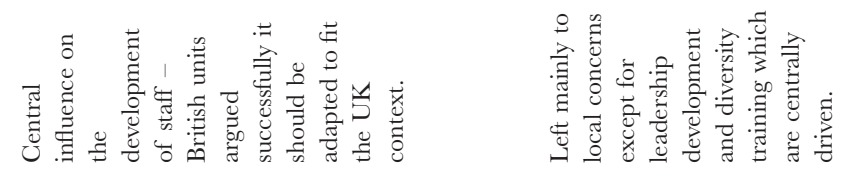

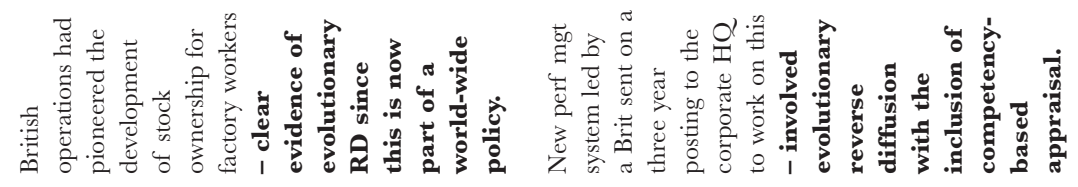

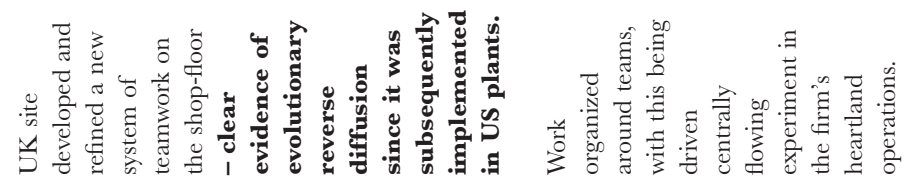

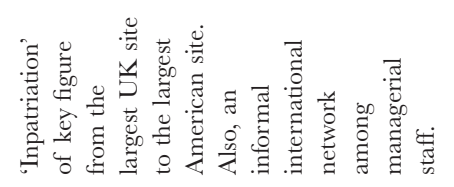

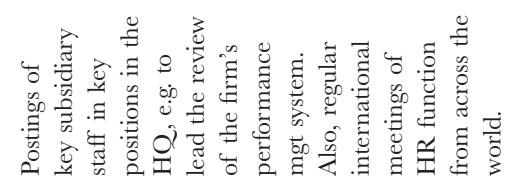

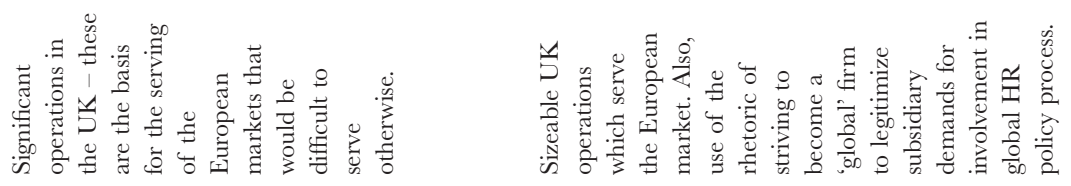

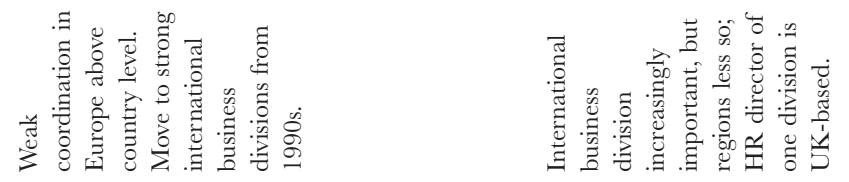

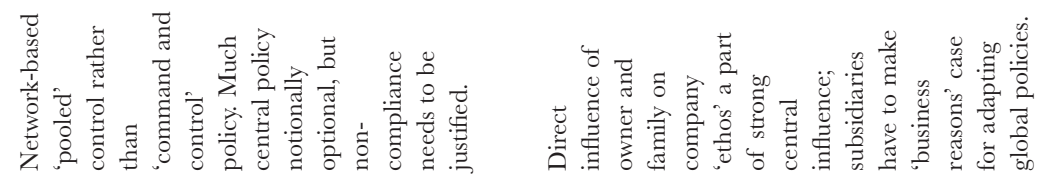

高

I 


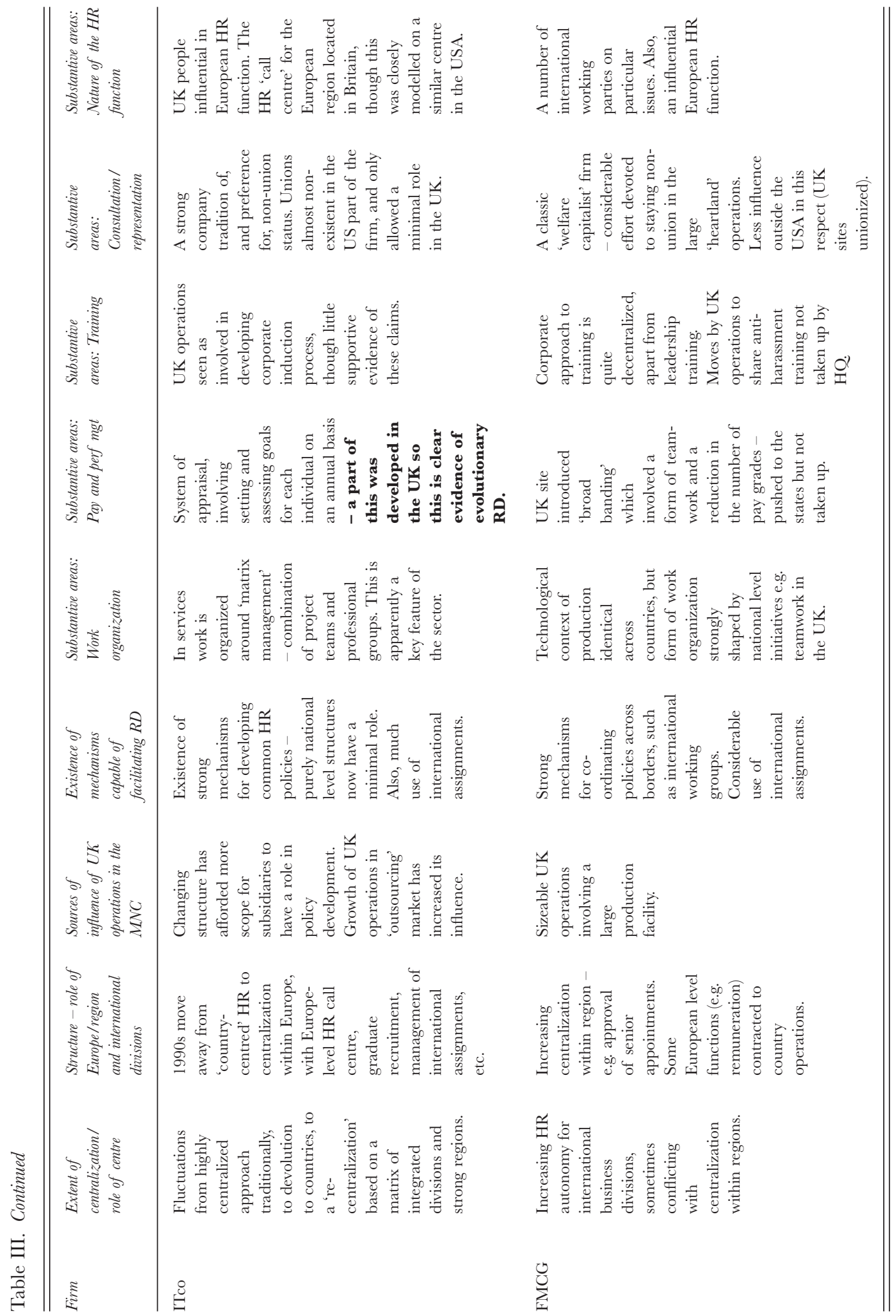


Three of these were found in Engco1, a company with a tradition of central influence in areas such as performance management and bonus plans. This coexisted with a growing role for UK plants with some aspects of the design and development function located in Britain. Indeed, there was evidence of the UK sites making innovations of interest to domestic sites.

One example was the introduction of a 'shared services' approach to organizing the HR function across the divisions in Britain. The British innovation generated interest in America and was significant in the company's shift towards the adoption of shared services in HR globally, but was described as the 'tip of the iceberg' in this shift with senior HR staff at corporate HQalready moving in this direction. Thus this is evolutionary $\mathrm{RD}$.

Another example was a share purchase plan developed in Britain. The company has a worldwide plan where an employee can buy shares to the value of between 1 and 6 per cent of salary and the company adds in shares of the same value. One manager described the way that this practice originated in Britain: '[The UK site] was the first facility in the world that put stock ownership, subsidized stock ownership on the factory floor. Now it's done in a lot of places'. The impact of the practice was constrained by the limits on the proportion of pay invested by those employees who took up the scheme. Crucially, the concept of stock ownership itself was not new, just the extension of it to shop floor workers. Thus this instance of RD also appears to be evolutionary.

A further example related to teamwork. The main British plant had developed a new layout for the production line involving a reorganization of teams. These teams elect 'co-ordinators', hold meetings every morning and are required to maintain a 'Continuous Improvement Processes' book. The Operations Manager of this plant indicated that they had drawn on the developments in the UK site which had been 'very successful in doing that' and went on to describe a 'lot of meetings with (the UK plant) on how they did it and things they would have done differently'. This case of RD certainly had a significant impact on the organization of production and work group relations. However, it was not transformative because the concept of teamwork already existed and, hence, the changes were relatively minor adaptations to existing practices rather than radical shifts to new ones. Therefore, the UK initiative was going with the grain of the company's established direction.

The fourth instance of RD was in Engco2, which has been strongly shaped by its 'founding family'. A strong corporate influence in such areas as diversity reflected the family's ethos, and the multinational adopted quite a centralized approach to HR. Many American respondents admitted that there had been, as one put it, a 'myopic view of the world that was HomeTown-centric'. Many HR leaders outside America have argued that the strong central influence is incompatible with the company's aspirations to be truly global and that they should be allowed more input into policy development. This issue rose to the surface at a 
corporate HR conference with one UK HR person effectively leading a 'revolt' at the conference.

Following the conference, the UK and Indian HR leaders were given responsibility for designing a new 'template' guiding the future development of international HR policies, a key part of which was subsidiary involvement. This approach was adopted in the design of a new performance management system, led by the British conference 'rebel' on a three-year assignment in the HQ and co-ordinating a multi-national team of eight people from six countries. This review incorporated practices from outside the USA into the new system, the prime example of which was the inclusion of a competency-based appraisal system pioneered in the UK. This is clear evidence of $\mathrm{RD}$, with its impact being evolutionary rather than transformative because it was a refinement to a direction that was already set by the working party's brief of tying the process of performance management more closely to training needs. However, the review of the performance management system did not operate in quite the participative way envisaged. The UK leader of the review admitted that 'participation was problematic' and an American on the team stated that 'quite honestly ... we did not in hindsight do what we should have to keep particularly the international people linked into this'. After three meetings the team disbanded, affected by a marked downturn in the company's fortunes in 2001 that led to a ban on all non-essential travel. This effectively derailed the vision of participative policy making, and the 'templates' for policy formation are not in evidence any more. In sum, this initiative did lead to one instance of evolutionary $\mathrm{RD}$, but the impact of the review of policy-making had a more minor impact than seemed likely at first.

The remaining instance of RD was in ITco, which has a long tradition of the centre exerting influence over employment practice. The British operations have played a significant role in the wider company, partly through the rapid growth in the IT outsourcing market and, more specifically, through the prominence of British HR practitioners. Senior HR positions in the European region were disproportionately staffed by Britons, and the European HR function had recently consolidated its administration into one centre, which was located in the UK. This would appear to position them to bring about RD. Accordingly, British respondents indicated that they had made innovations to the firm's global appraisal process by requiring each employee to set a series of goals and areas for developments at the beginning of each year and for these to be used as the key measure of achievement in the annual appraisal. This is clearly a significant development, but a careful reading of its operation reveals that it amounts to a fine-tuning of existing practice rather than a radical change; it constitutes a particular way of identifying and assessing personal goals, but works within a pre-established system of individual appraisal that is linked to a 'forced distribution' that in turn determines each employee's annual pay rise. Hence, it is an evolutionary rather than a transformative change. 
In the other two MNGs there was no evidence of RD. In Eng Services the UK operations have such a key position within the firm that it has the potential to spread practices to other sites. It has been the most profitable part of the firm, and has served as the bridgehead into Europe, Middle East, South-East Asia and South Africa. Recently, the HQ of one of the firm's two divisions has been relocated to Britain. One example of a practice developed in Britain is a performance management system that was designed to provide a more systematic and holistic approach to skill formation. A similar practice has been implemented in Spain, though it was not clear how directly this was modelled on British practice. While it is conceivable that this is an instance of 'horizontal' diffusion across foreign sites, there is no evidence that it has been transferred back to the American operations. This is mainly because of the weakness of the coordinating mechanisms across its international operations. There were some signs of change in this respect, with moves towards establishing more in the way of global policies in areas such as engineering practice and project management standards, which had some limited HR implications. However, these moves have now been abandoned and the firm has returned to a highly decentralized approach. The mechanisms that could promote the co-ordination of employment policies are generally weak. For example, international management committees only meet sporadically and appear to have little role in diffusing employment practices.

In the final company, FMCG, there was also no evidence of RD. Here, the corporate HR function has made limited moves towards involving people outside the US in policy development. For example, international working parties are looking at common policies on 'variable compensation' and 'leadership training capabilities', both of which are being led by Europeans. As an American HR manager put it: 'So there's opportunities from a country level to participate on teams, global functional teams, and also to participate on global process design'. This would appear to create scope for RD.

However, the British operations appear to have struggled to get the Americans to adopt practices developed in the UK. British managers tried and failed to attract interest from their American counterparts in relation to a new approach to developing potential supervisors and anti-harassment training. Perhaps the most significant innovation at UK site level was in relation to 'broad-banding' involving the creation of teams and a simplification of the grading structure. While previously there had been twenty pay grades, this was reduced to six pay 'bands' (with this effectively being five given that the lowest one is hardly used) related to skill sets. Within each band there are only two pay rates, meaning that there are now only ten pay rates across the entire manufacturing workforce, half the previous number. British managers claim that they brought this practice to the attention of the parent firm but they did not seem interested. One UK manager who had worked this system in the UK and then been on an assignment in the US described his attempt to share the new UK practice in the company's heartland operation: 'while 
I was there I did some work with them on moving towards broad-banding, but I don't think they went there'.

Overall, in each of these cases there is evidence of UK subsidiaries having developed practices that other sites may be interested in, partly as an attempt to develop responsibilities beyond their own plant. However, the impact of RD is limited: some practices were simply overlooked by the HQ, such as 'broad-banding' at FMCG; some attempts to encourage RD were derailed before being implemented, of which the performance management review at Engco2 is an example; some instances of diffusion from British sites were only to other European sites and were not transferred to the USA, such as individual pay at Eng Services; and even where it did occur the instances of RD we uncovered were evolutionary rather than transformative in their impact, which is the case in the appraisal process at ITco and teamwork at Engcol. This is surprising given the prevalence in our case study firms of the corporate characteristics that promote $\mathrm{RD}$ and the grounds for expecting US MNCs to be favourably disposed to RD that we established at the outset. Hence, we see the task as being to explain the limited impact that RD had in our case studies, and it is to this that we now turn.

\section{BARRIERS TO REVERSE DIFFUSION}

In explaining the findings we revisit the three arguments that led us to expect RD to be significant in US MNGs. These were: the weakness of labour market regulations and unions in the USA; the disposition towards radical innovations in American firms; and the structure of American MNCs which encourages subsidiaries to develop distinctive capabilities. We use the data to argue that all three of these initial expectations are flawed, and that the US business system actually presents a number of barriers to RD.

First, while American managers are more likely than their counterparts in most other developed countries to be free from the constraints of regulations or unions in introducing new employment practices, other constraints arise in the form of pre-existing HR policies. The prime example of this was at FMCG. As described above, the UK operations had developed a system of 'broad-banding' involving teamwork. Teamwork is widely used in American firms (Colling and Clark, 2003) but FMCG's American sites did not pursue this despite one of the UK managers going to some lengths to share information about the new practice. The lack of interest from his American colleagues can be explained by the union avoidance policies in place at the main US site.

Jacoby (1997) describes a management style prevalent among many large American firms throughout the twentieth century that he terms 'welfare capitalism'. This approach, Jacoby argues, was often inspired by a 'founding father' whose paternalistic values strongly informed the corporation's policies. Such firms commonly operate internal labour markets designed to tie skilled workers to the firm, 
with pay levels generally comparing well with alternative forms of employment. Indeed, the setting of pay is part of a fierce ideological commitment to keep unions out of the firm. Hence, welfare capitalist firms, of which FMCG is a prime example, have tended to closely monitor the structure and levels of pay in unionized firms, and to ensure that their own systems compare favourably.

In this context, the British innovation of simplifying the pay system into fewer bands was unattractive to American managers. While the pay structure in the American plant contains seniority provisions, the British system involved a closer relation between pay and skills. Furthermore, the American plant used multiple job grades, apparently representing an attempt to emulate the structures, and improve upon the levels, of pay in nearby unionized firms. If the British practice had been implemented in the USA, the shift would inevitably have resulted in some workers perceiving themselves to have lost out from the changes, relatively or absolutely, and might therefore have provided fertile ground for unions to make membership gains. In this way, the commitment to retaining non-union status in welfare capitalist firms constrains the scope for innovation by managers.

Moreover, while it is the case that unions are generally weak in the USA, there is a sub-set of large American firms that continue to bear the legacy of the 'New Deal', such as the automotive producers. In these firms, the role of detailed procedures and elaborate pay scales together with the need to negotiate major changes to working practices with union representatives (Kochan et al., 1994) would also make the introduction of a significant re-organization of pay grades problematic. The prevalence of these two types of firm, and the competitive relationship between them, therefore, present significant barriers to the reverse diffusion of many types of employment practice. This is particularly the case in the north-east and mid-west of the country where unions are strongest, and where welfare capitalist firms are therefore in the fiercest competition with unionized firms. The corollary is that this barrier to RD is lowest in the south where unions are weakest and where a welfare capitalist style is rarely necessary to keep unions out. The Engcol case is consistent with this since the reverse diffusion of teamwork was received by the site in North Carolina, a 'right-to-work' state where union membership is only 5 per cent. The evidence from the site confirmed that maintaining non-union status is not a problem for management.

Overall, it seems that the weakness of labour market regulations does not give US MNGs as much freedom to engage in RD as anticipated, particularly in relation to pay. Moreover, evidence from MNGs from CMEs covered in the literature review showed that the barriers to $\mathrm{RD}$ from the regulated labour markets that characterize these countries are often not particularly strong; it points to numerous instances of transformative RD in German, French and Swedish MNCs in areas such as pay. More generally, the regulations in labour markets in CMEs are more malleable to MNGs than their formal nature would suggest (e.g. Muller, 1998; Royle, 1998). Furthermore, other aspects of labour markets in CMEs might 
make them more receptive to RD. For instance, in Germany the broader skills that employees possess may equip them to operate a wider range of practices than their more narrowly skilled counterparts in the USA, providing more fertile ground for the introduction of novel employment practices that require employee adaptability (Edwards and Ferner, 2004). Another possible instance concerns the consultative, partnership-based tenor of IR in some CMEs such as Germany, which might facilitate the implementation of new practices; in contrast, the adversarial nature of management-union relations in unionized firms in the USA may obstruct this process.

The second argument - that a tendency for firms to make radical changes would be conducive to RD - can also be questioned. Certainly, our evidence demonstrates that basic strategies and structures fluctuate markedly and repeatedly in large American firms. This is due to the institutional influences from the American business system, particularly in the financial markets. Pension funds, unit trusts and other investors, despite their 'arms length' relationship with firms, have become increasingly influential over senior managers (O'Sullivan, 2000). Accordingly, managements in our case study firms have made radical changes in strategy in order to appease shareholder concerns. For instance, ITco had undertaken a dramatic shift in structure in response to corporate crisis; the moves towards greater decentralization that had become well established were reversed, being replaced with a matrix structure. In addition, the firm moved into an entirely new area, IT services, and has since grown rapidly in this area. Another example was in Engco2 where a new CEO was appointed with a brief of 'shaking things up'. He emphasized the need to generate a stronger 'performance ethic', something that was clearly aimed at external shareholders.

A further aspect of the response of US firms to financial market pressures is their tendency to make rapid cuts in budgets and jobs in response to market downturns. This played a crucial role in the review of the performance management system at Engco2; many respondents argued that the company had coped with market fluctuations to a greater extent previously, something that was facilitated by the founding family's controlling stake. Now, however, the family has significantly reduced its stake and the firm is owned by a range of financial institutions that have less attachment with senior management. A key consequence has been the need to send signals to these institutions that product market downturns are being treated seriously and that management are taking swift action. It was the deep cuts, including the freeze on international travel, in response to the downturn of 2001 that derailed the emphasis on participative policy making across countries.

A different though related example was in Eng Services. During the 1990s the firm had strengthened global corporate functions, reversing understandings about operational sovereignty at subsidiary level, partly as a response to major problems in some operations. The instigating of global corporate functions appeared to be 
making RD more likely since it provided mechanisms linking the US sites to those elsewhere. The highly profitable UK operations were well placed to serve as donor units for new practices given these developments. However, the appointment of a new CEO led to a dramatic reversal of the strategy of building these global functions, seriously curtailing the scope for RD. Compounding this has been a tendency for the US operations to respond to downturns with deep job cuts, particularly among the expensive process engineers. Arguably, this has limited the scope for the US part of the division to upgrade itself - through introducing practices developed in the foreign subsidiaries, for example - when conditions change.

Thus, the tendency for radical change in corporate strategies and structures in general, and the swift and dramatic responses to changes in market conditions in particular, have actually constrained RD. While the ease with which resources can be moved from one use to another within the USA may allow companies to reinvent themselves with dramatic shifts into new areas as Hall and Soskice (2001) argue, this fluidity appears to impede the international co-ordination that is necessary for RD to occur. Building close links between site level actors in different countries takes time, often arising from a lengthy process of coalition building and cross-national learning (Birkinshaw, 2000). Arguably, in CMEs the institutional context leads companies to evolve more gradually, responding to changes in markets in a slower, more measured manner, providing a more stable, and therefore more conducive, context in which RD can take place. In sum, the second of our initial expectations also seems to have been heavily qualified.

The third reason highlighted at the outset as promoting RD also needs to be questioned in the light of the evidence. The structure of all five case studies afforded some scope for the British subsidiaries to develop 'distinctive organizational capabilities'. However, there were two aspects of their structure and organization that impeded RD, demonstrating the important political dimension to this phenomenon.

One of these was the extent of central influence on employment policy. It is evident that the balance between centralization and decentralization in US MNCs varies significantly both between firms and also over time within firms. While some American multinationals do devolve responsibility for operational issues such as HR to country or site level in the way that Whitley (2001) predicts, there is also a strong tradition of centralization over HR and IR issues in US MNGs that should be seen as an extension of the way that large American firms operate within the US (Ferner et al., 2004). Neither highly centralized nor highly decentralized approaches are particularly conducive to RD. The rapid fluctuations between these two extreme positions that is characteristic of some of our case studies are also unpropitious for RD.

In highly centralized companies, such as ITco, Engco2 and FMCG, this influence does not close off all scope for innovations at foreign subsidiary level; our evi- 
dence indicates that the UK sites often look to expand their role within the wider firm through supplying expertise and knowledge to other sites. However, the tradition of centralization has created an assumption that international policies should be initiated by those at corporate level. One consequence is the existence of a significant organizational group that may resist RD, namely a well-staffed and influential HR function. This group may feel threatened by subsidiaries becoming more involved in the policy-making process, fearing that the logic of this development will be a reduction in headcount amongst their group and a fall in their status.

Our evidence of this is indicative only. Within Engco2 the break with the HQ driven model of developing global HR policies clearly posed a threat to many in the central HR function. The reversion to the HQ driven model represented the removal of this threat. The privileged claim on resources of the corporate HR function was raised directly by one of our British respondents in FMCG who expressed amazement at the number of people in the corporate HR function. Where this is the case, it might be argued that there is likely to be resistance to RD. Therefore, the failure of many US MNGs to engage in RD may be a result of political activity by those in the HQ who see their prominent role in policy making threatened by subsidiary involvement.

At the other end of the centralization-decentralization spectrum, the marked devolution of responsibility for $\mathrm{HR}$ and IR issues to foreign units may also constrain the scope for RD. In decentralized firms such as Eng Services the high degree of decentralization and the absence of a co-ordinating role from the centre constrained the obvious potential of the highly profitable UK operations to diffuse practices to the American sites.

It appears that neither a highly centralized nor a highly decentralized approach promotes RD. Rather, the structure that is most conducive to it is an international network such as that envisaged in Bartlett and Ghoshal's 'transnational' firm in which a number of sites have responsibility beyond their immediate environment and in which actors from across the organization are engaged in policy development (see Edwards and Ferner, 2004). While there were some moves towards this type of structure in our case studies, these were based mainly around regions.

The regional dimension of the structure of US MNGs is a further barrier to RD. There is abundant evidence concerning the concentration of FDI in the three main regions of the global economy, namely North America, Europe and AsiaPacific (e.g. Rugman, 2000). Institutions and regulations are emerging that cross borders within a region, but which are separate from those in other regions. In this vein, Marginson argues that Europe has become 'an economic, political and regulatory space whose character and dynamic are distinctive when set against wider, global, developments or those in the other two "Triad" regions' (2000, p. 11). Marginson reviews evidence indicating that MNGs are placing increasing 
emphasis on the European, as opposed to national or global, elements within their structures.

The European dimension to the structure was particularly important in ITco and FMCG, and to a lesser extent in Eng Services. Such structures can provide a focal point for the European subsidiaries to influence the development of global policies. Indeed, in FMCG the European entity appeared to be having some influence on the development of global policies on issues such as variable pay, as described above. However, another impact of the regional dimension was to generate close links between the British and other European sites, but simultaneously to curtail direct contact between the British and American sites. This appeared to be the case in ITco, where the UK operations had pioneered several initiatives within the European HR function, such as the operation of the administration centre, but had a much more limited role in developing policies in North America. The story in Eng Services is similar, where the UK operations have enjoyed something of a 'regional mandate' within Europe and the Middle East, leading the creation of new subsidiaries in this area and managing them for a time, but having much less influence on the other side of the Atlantic.

Thus this regional integration promotes a degree of networking and subsequent diffusion of practices across sites within regions, but its impact on RD across regions is ambiguous. Of course, where firms are organized around a matrix the divisional aspect of the structure can still promote RD, and the strengthening of regional structures within US MNCs may actively promote RD from Canada or Mexico, though in the former the extent of this may be limited by the relative size of the Canadian economy and in the latter by the scale of the institutional and cultural divides between the US and Mexico and by the 'sweatshop' role that some Mexican subsidiaries of US MNCs sometimes play. Within European MNCs, the deepening of regional structures has a much clearer effect in promoting RD through the strengthening of links between the domestic operations and a number of potential donor units.

The combination of these two aspects of American MNGs - the highly centralized or highly decentralized approach to decision making and the growing importance being placed on regional structures - strongly qualifies the third of the reasons we established as being likely to promote RD. While many American MNCs allow foreign units sufficient operational autonomy within tight financial controls to develop the distinctive capabilities to which Whitley refers, they often fail to transfer these capabilities to the home country: those firms that are highly decentralized may lack the integrative mechanisms that provide a channel through which these units can spread their expertise; in those with a strong tradition of centralization there may well be political resistance to RD; and among those in which a degree of international networking exists this is commonly organized around regions. For these reasons, therefore, the structure and organizational politics of US MNGs appear to be further barriers to RD.

(C) Blackwell Publishing Ltd 2005 


\section{DISGUSSION AND GONGLUSION}

The paper has demonstrated that the US business system presents important barriers to RD. We established a priori grounds for expecting the US business system to be conducive to RD: the deregulated labour market; the disposition of American firms to make radical changes; and their tendency to devolve considerable operational responsibility to foreign units. However, the rich case study data enabled us to reveal a more complex picture, with the barriers presented by the American system proving significant.

One important implication is that transferring innovative practices developed in foreign subsidiaries is more difficult to realize than sometimes assumed. Many models of strategic management in MNGs and of IHRM suggest that MNCs can significantly enhance their competitive position by tapping into the range of practices in place across their international operations. Much of this work adopts an 'information processing' perspective involving a focus on flows of information and knowledge between different units of MNGs. The idea that tapping innovative practices across a multinational is a primary source of competitive advantage is central to the 'resource-based view' of the firm utilized by Taylor et al. (1996) in their 'integrative model of IHRM'. Our analysis of the data has revealed that there are deep-rooted barriers to RD which the information processing and resource-based approaches tend to neglect.

While the information processing and resource based views have little to say on the persistent influence of the distinctive institutional configurations of a multinational's home business system, Bartlett and Ghoshal do discuss what they refer to as the 'administrative heritage'. This is defined as a company's 'existing organizational capabilities as shaped by various historical and structural factors' (1998, p. 39). This administrative heritage, which the authors argue makes firms to some extent 'captives of their past', stems from some factors internal to the organization, such as the role of the firm's founders. It also stems from the impact of national culture, which gives a firm 'a way of doing things'. While this is an advance on the limitations of the information processing perspective and resourcebased view, we argue that Bartlett and Ghoshal neglect some of the difficulties that firms face in shedding this heritage. Our focus on institutions indicates that the domestic business system continues to exert a distinctive and significant influence that firms cannot easily shed. This is the case not just in terms of the implementation of practices in the domestic sites in the way we have shown, but also in terms of the strength of the 'country of origin' effect in the wider firm, something that was a key finding of the research project of which this paper is a part (Almond et al., 2003).

Indeed, we argue that an institutional approach adds significantly to our understanding of RD. The distinction between LMEs and CMEs was a useful starting point, but a variegated approach that is sensitive to nationally distinct institutional 
configurations was more helpful. In the case of the USA, we have seen how the institutions in the labour and financial markets, in particular, present barriers to RD. The primary focus on institutions does not lead us to deny that there is a role for culture in our analysis. Prevalent attitudes and values differ across countries, and these differences are a part of the distinct contexts across which practices are transferred. However, these cultural differences emerge in, and are sustained by, the institutional facets of national business systems, and a cultural approach that ignores these institutional differences would appear to have little purchase in explaining the patterns in our data.

Nevertheless, our data do point to the limitations of institutional approaches; $\mathrm{RD}$ is clearly also a political phenomenon in that the extent to which it occurs and the consequences it brings are dependent on the preferences of organizational actors and the power resources that they control. Hence, an institutional approach must be sensitive to the role of powerful individuals and groups within MNCs if it is not to be guilty of determinism. One illustration of how institutional and political approaches can be integrated is by seeing institutions as constantly evolving through a series of small and cumulative changes instigated by groups who see this evolution as promoting their interests, a process referred to as 're-institutionalization' (Djelic and Quack, 2003). While incorporating a political dimension into institutional analysis leads to a recognition that institutions do not have determining effects, the logic of this perspective is that there remains a degree of predictability in the behaviour of firms embedded in a distinctive institutional context.

A key implication of the paper is that in comparison with MNGs from other countries, the barriers to RD will be distinct but not necessarily less significant in American multinationals. While the clearly codified nature of structures of employee representation in countries like Germany present restrictions on the managerial prerogative that American firms do not face, these structures rarely tie the hands of management entirely, and practices negotiated through this route may be received with less scepticism by employees than those that are imposed. Moreover, while we had anticipated that a disposition towards radical change in American MNCs would make RD more likely, we found that this can impede the development of learning and coalition building in 'downstream' functions like HR. In contrast, the tendency towards more incremental, gradual changes among MNCs from CMEs might provide a more stable context within which such learning and coalition building can take place. In relation to the structure and organization of MNGs, while we have seen that regional structures act as barriers to RD in American MNCs, they may actively promote RD within MNGs originating in other countries. Of course, there will be other barriers to RD presented by the more regulated, co-ordinated market economies faced by German, French, Swedish and Japanese MNGs that their American counterparts will not feel so strongly. Therefore, we cannot say with confidence that they will be weaker in 
Germany, for instance, than in the USA; what we can say is that the nature of these constraints varies by national context and that they are more significant in the USA than we had anticipated.

Finally, the relative absence of RD in our case study companies, particularly transformative instances, may be related to three factors. First, it may reflect the sectors from which our case studies are drawn. The sectors concerned - mechanical engineering, civil engineering, chemical production and IT services - are perhaps not those in which the British business system possesses major strengths, and the findings may have been slightly different had case studies been drawn from, say, finance or business services. However, it is unlikely that the results would have been greatly different because the subsidiaries examined were generally thriving and profitable and had made a number of innovations in the employment field; the institutional and political barriers that applied to these firms would apply to firms from any sector. Second, the findings may be related to patterns of national economic performance in the last decade or so. The superior performance of regulated and co-ordinated economies such as Germany and Japan was widely recognized in the 1980 s and led to a sense of crisis in the USA that was vividly expressed by writers such as Dertouzos et al. (1989) and Locke (1996). Many American companies appeared to be seeking to emulate the practices of Japanese firms in particular (Maccoby, 1997), and we might expect that they were favourably disposed to RD more generally in this period. In contrast, the conventional wisdom of the last ten years has been that the American business system provides the flexibility necessary to cope with rapidly evolving economic and technological conditions, and American firms have reasserted themselves in international markets. Thus a study such as ours may have produced slightly different findings had it been conducted a decade earlier, though the institutional barriers to RD that we have identified would also have constrained the extent of the phenomenon in earlier periods, of course. Third, the absence of transformative RD may reflect the focus on the British subsidiaries. There are certainly good reasons for expecting the British plants to be well-placed to act as sources of reverse diffusion, but maybe the similarities between the two business systems mean that where this does occur the instances are mainly evolutionary in nature, going with the grain of preexisting practices. In this respect, an interesting subsequent step would be to examine the role of subsidiaries from quite different business systems within American MNGs.

\section{REFERENGES}

Almond, P., Clark, I., Colling, T., Edwards, T., Ferner, A. and Holden, L. (2003). US Multinationals and the Management of Human Resources in Britain. Leicester: Leicester Business School.

Bartlett, C. and Ghoshal, S. (1998). Managing Across Borders: The Transnational Solution to Managing Across Borders, 2nd edition. London: Hutchinson. 
Belanger, J., Berggren, C., Bjorkman, T. and Kohler, C. (1999). Being Local Worldwide: ABB and the Challenge of Global Management. Ithaca, NY: ILR Press.

Bird, A., Taylor, S. and Beechler, S. (1998). 'A typology of international human resource management in Japanese multinational corporations'. Human Resource Management, 37, 2, 159-72.

Birkinshaw, J. (2000). Entrepreneurship in the Global Firm: Enterprise and Renewal. London: Sage.

Colling, T. and Clark, I. (2003). 'The Character and Diffusion of Teamworking Programmes in the British Subsidiaries of Two American Multinational Companies'. Paper presented at IHRM conference, Limerick, $4-6$ June.

Cutcher-Gershenfeld, J. et al. (1998). Knowledge-Driven Work: Unexpected Lessons from Fapanese and United States Work Practices. Oxford: Oxford University Press.

Dertouzos, M., Lester, R., Solow, R. and the MIT Commission on Industrial Productivity (1989). Made in America: Regaining the Productive Edge. Cambridge, MA: MIT Press.

Djelic, M. and Quack, S. (Eds) (2003). Globalization and Institutions: Redefining the Rules of the Economic Game. Cheltenham: Edward Elgar.

Edwards, T. (1998). 'Multinationals, employment practices and the process of diffusion'. International Fournal of Human Resource Management, 9, 4, 696-709.

Edwards, T. (2000). 'Multinationals, international integration and employment practice in domestic plants'. Industrial Relations fournal, 31, 2, 115-29.

Edwards, T. and Ferner, A. (2004). 'Multinationals, reverse diffusion and national business systems'. Management International Review, 44, 1, 49-79.

EIRO (2002). 'Industrial Relations in the EU, Japan and USA'. www.eiro.eurofound.ie/2002/12/ feature/TN0212101F.html.

Ferner, A. and Quintanilla, J. (1998). 'Multinationals, national identity, and the management of HRM: "Anglo-Saxonisation" and its limits'. International fournal of Human Resource Management, 9, 4, 710-31.

Ferner, A. and Varul, M. (2000). "Vanguard" subsidiaries and the diffusion of new practices: a case study of German multinationals'. British Fournal of Industrial Relations, 38, 1, 115-40.

Ferner, A., Almond, P., Clark, I., Colling, T., Edwards, T., Holden, L. and Muller-Camen, M. (2004). 'The dynamics of central control and subsidiary autonomy in the management of human resources: case study evidence from US MNCs in the UK'. Organization Studies, 25, 3, 363-91.

Foss, N. and Pedersen, T. (2002). 'Transferring knowledge in MNCs: the role of sources of subsidiary knowledge and organizational context'. Fournal of International Management, 8, 49-67.

Hall, P. and Soskice, D. (2001). Varieties of Capitalism: The Institutional Foundations of Comparative Advantage. Oxford: Oxford University Press.

Hayden, A. and Edwards, T. (2001). 'The erosion of the country of origin effect: a case study of a Swedish multinational company'. Relations Industrielles/Industrial Relations, 56, 1, 116-40.

Jacoby, S. (1997). Modern Manors: Welfare Capitalism in the Twentieth Century. Princeton, NJ: Princeton University Press.

Kochan, T., Katz, H. and McKersie, R. (1994). The Transformation of American Industrial Relations. Ithaca, NY: ILR/Cornell University Press.

Kurdelbusch, A. (2002). 'The rise of variable pay in Germany'. European fournal of Industrial Relations, $\mathbf{8}, 3,325-49$.

Lam, A. (2003). 'Organizational learning in multinationals: R\&D networks of Japanese and US MNEs in the UK'. Fournal of Management Studies, 40, 3, 673-703.

Lane, C. (2001). 'The emergence of German transnational companies: a theoretical analysis and empirical study of the globalisation process'. In Morgan, G., Kristensen, P. and Whitley, R. (Eds), The Multinational Firm: Organizing Across Institutional Divides. Oxford: Oxford University Press.

Locke, R. (1996). The Collapse of the American Management Mystique. Oxford: Oxford University Press.

Maccoby, M. (1997). 'Just another car factory? Lean production and its discontents'. Harvard Business Review, 75, 6, 161-8.

Marginson, P. (2000). 'The EuroCompany and Euro industrial relations', European Fournal of Industrial Relations, 6, 1, 9-34.

Mtar, M. (2001). 'French Multinationals' International Strategy'. PhD thesis, University of Warwick.

Muller, M. (1998). 'Human resource and industrial relations practices of UK and US multinationals in Germany'. International fournal of Human Resource Management, 9, 4, 732-49.

O'Sullivan, M. (2000). Contests for Corporate Control: Corporate Governance and Economic Performance in the United States and Germany. Oxford: Oxford University Press. 
Royle, T. (1998). 'Avoidance strategies and the German system of co-determination'. International Journal of Human Resource Management, 9, 6, 1026-47.

Rugman, A. (2000). The End of Globalization. London: Random House.

Sally, R. (1996). States and Firms: Multinational Companies in Institutional Competition. London: Routledge.

Sewell, G. and Wilkinson, B. (1993). 'Human resource management in "surveillance" companies'. In Clark, J. (Ed.) Human Resource Management and Technical Change. London: Sage.

Taylor, S., Beechler, S. and Napier, N. (1996). 'Toward an integrative model of strategic international human resource management'. Academy of Management Review, 21, 4, 959-85.

Tempel, A. (2001). The Cross-National Transfer of Human Resource Management Practices in German and British Multinational Companies. Mering: Hampp.

UN (2002). World Investment Report: Transnational Corporations and Export Competitiveness. New York: UN.

Whitley, R. (2001). 'How and why are international firms different? The consequences of crossborder managerial coordination for firm characteristics and behaviour'. In Morgan, G., Kristensen, P. and Whitley, R. (Eds), The Multinational Firm: Organizing Across Institutional Divides. Oxford: Oxford University Press.

Whitley, R., Morgan, G., Kelly, W. and Sharpe, D. (2003). 'The changing Japanese multinational: application, adaptation and learning in car manufacturing and financial services'. Fournal of Management Studies, 40, 3, 643-72. 